\title{
IS THERE A FE(MALE) APPROACH IN CUSTOMER RELATIONSHIP MANAGEMENT?
}

\author{
Tedy Herlambang* \\ Universitas Ma Chung Malang
}

\begin{abstract}
Customer relationship management (CRM) has been the favorite topic of scores of marketing consultants and academicians for over a decade. CRM approaches marketing as dating in which the marketer attempts to turn strangers into friends and friends into lifetime partners and to retain the loyalty of the right customers for this is the key to long-term profits in a company. Gender theories posit that women and men behave differently, and that they approach things differently. Moreover, these theories have documented a picture of women are being more expert and motivated relationship psychologists than men, as more active in their relationship monitoring, and as more oriented toward the maintenance and success of their relationships. Based on these theories, this paper develops some propositions to facilitate its empirical testing related to relationship communication and relationship dissolution in business market. The contribution of this paper is twofold. First, it attempts to create more insight into areas where relationship marketing research to date has not been abundant. Second, this paper attempts to contribute to methodological development of measuring relationship success by systematically distinguishing between good communication relationship and good management relationship.
\end{abstract}

Keywords: customer relationship management, relationship communication, relationship dissolution

\section{Introduction}

Customer Relationship Management (CRM) approaches business marketing as dating in which the objective is to form a long-term and mutually beneficial relationship. From this perspective, the marketer attempts to turn strangers into friends and friends into lifetime partner and to retain the loyalty of the right partner for this is the key to long-term profits in a company. CRM involves the development of continuous relationships with customer that are usually long-term, 49,50 dynamic and that entail acquiring information based on communication, which should be proactive and defined in the customer's terms.

Firms are continuously acting, interacting and developing in their environments. In the marketing discipline, exchange has been accepted as a core concept (Bagozzi 1975; Hunt 1991). Market exchange takes place because all parties involved expect to gain value from the exchange. Therefore, obtaining value has always been the fundamental basis for all marketing activity (Holbrook 1994). Value arises through the medium of exchange in the sense that economic surplus (gains from trade) is realised (Bowman and Ambrosini 2000). However, exchange itself is costly (Foss and Foss 2002) and complex (Aldrich and Whetton 1981).

Partners in business-to-business relationship want their relationships to be profitable. But the particular routes to profitability for trading partners do not strictly coincide with each other as in business markets the preferences of sellers and buyers are different (Dwyer and Tanner 2002). Conflict between partners centres on fairness and justice related to cost and value sharing in exchange. Conflict may arise because the partners differ in their perception of what is a fair price for the bundle of attributes to be exchanged and even the composition of the bundle of attributes (Thomas and Wilson 2003). Parties transact for a variety of reasons and exchange different contents (Sydow 1998). This process is made more complex by the 
fact that each party to the exchange may not have similar or even compatible objectives in a transaction and may place different weights on activities undertaken and the resources forfeited (Goldman 1966).

Furthermore, buyers or sellers in business markets do not only seek financial rewards in relationships. They also want integrity, fairness, loyalty, flexibility, consideration in partner's strategy, partner's participation in their own strategies, and compliance with established administrative procedures (Dwyer and Tanner 2002). While conflict is as pervasive a phenomenon in inter-organizational systems (Ireland and Webb 2007), value can be created by reducing conflicts.

As value can be increased by reducing the level of conflict in relationship, gender differences theories could be useful to give insight on how to build successful relationship in business to business relationship. The gender theories have documented a picture of women being more expert and motivated relationship psychologists than men, as more active in their relationship monitoring, and as more oriented toward the maintenance and success of their relationships. This paper will explore the possibilities of implementing a fe(male) approach in handling conflict base on gender theories into buyer-seller relationship context.

The main idea of CRM

To the seller a market is a collection of buyers and potential buyers, some of whom can be attracted in to exchanges by tempting offers. To the buyer, a market is a set of supplierproduct offerings from which to choose. Thus, a market is a source of rewards for exchanging, of expertise to do something, of information, and of referent power.

Relationship Marketing is the central philosophy underlying the Customer Relationship Management and has become part of the 'plausible story' of the now burgeoning Customer Relationship Management. In marketing literature Gronroos (1994) defines relationship marketing as a strategy 'to identify and establish, maintain and enhance relationships with customers and other stakeholders, at a profit, so that the objectives of all parties involved are met. This is done by a mutual exchange and fulfillment of promises. From promises and expectations, the exchange of values leads to satisfaction, trust, commitment, interdependence and loyalty. This suggests that profit is the organisational outcome of the relationship. Profit is received in many forms, not only monetary.

Relationship marketing has dual focus: of catching and keeping customers and developing long-term relationships between organizations (Rentschler 1999). In relationship marketing the emphasis is on the interdependent ingredient that will achieve long-term financial and social goals. The marketing activity moves from universal to individual and from generic to specific. Benefit of applying a relationship marketing perspective on customer relationship management may be a possible way of overcoming the lack of customer orientation, confusion over who the customers are and the short-term tactical focus (Gronroos 1994; Storbacka, Strandvik, and Grönroos 1994).

The relationship between an organization and a customer begins when the prospective customer is identified in a new segment to be targeted as part of the marketing mix strategy. Loyalty ladder builds through repeat interaction, purchase. Marketing through relationships, as compared to transactional marketing, means that interactions between the parties concerned are connected to both previous and future actions; also counterparts may become interdependent over time as they continue to interact (Moller and Wilson 1995).

Gronroos (1994) states that at the relationship marketing end of the continuum it is the quality of the relationship that be-comes important. As there is more than one interaction between the organization and the client, it is important that each of these interactions is positive in order to encourage the continuation of the relationship. Some of these interactions will be 
more important to the customer than others. Gronroos (1990) describes these interactions as moments of truth, similarly (Storbacka et al. 1994) describes it as critical episodes.

The marketing tactics or activities in building loyal partners are varied and involve information and financial exchange, interactions, risk, customer service and satisfaction, and the establishment of trust, commitment and interdependence. The more the organization learns about and monitors the patrons' needs, preferences, attitudes and concerns, the more their satisfaction and commitment levels grow. The more the patron learns about the organisation's needs and plans, the more opportunities for an interdependent relationship and organisational development are identified.

\section{Conflict}

Partners in business market want their relationships to be profitable. But to get profit, this is not all about the sweetness in relationship. Conflict is as pervasive a phenomenon in business-tobusiness relationship as it is in other inter-organizational systems (Ireland and Webb 2007). Conflict is related to opponent behaviour such as overt disagreement or resistance (Pondy 1967) which is direct and personal (Stern 1971). Conflict is awareness on the part of the parties involved of discrepancies, incompatible wishes, or irreconcilable desires (Boulding 1963). Conflict arises as actors are striving to attain perceived different goals manifested by mutual interference behaviour or blocking activities (Schmidt and Kochan 1972). At least one of these individuals or groups perceives the other as an opponent behaving so as to thwart, injure, destroy, or obtain scare resources at the expense of the perceiver (Goldman 1966).

Conflict can originate either in goal incompatibility or in hostility (or in both), and that it involves a unique type of behavior, conflict behavior. Thus conflict is defined here as a situation in which actors use conflict behavior against each other to attain incompatible goals and/or to express their hostility.

Conflict can be affective or cognitive (Pinkley 1990; Amason 1996). Cognitive conflict pertains to conflict about ideas and differences of opinion about the task (Amason and Sapienza 1997). Affective conflict, an awareness of interpersonal incompatibilities, includes affective components such as feeling tension and friction. Affective conflict involves personal issues such as dislike among partners and feelings such as annoyance, frustration, and irritation (Pinkley 1990; Amason 1996).

A third type of conflict is process conflict (Jehn 1997; Jehn, Northcraft, and Neale 1999). It is related to an awareness of controversies about aspects of how task accomplishment will proceed. More specifically, process conflict pertains to issues of duty and resource delegation, such as who should do what and how much responsibility different people should get and justice.

Justice, the rendering of what is merited or due, results from the fair and respectful use of power. Even handedness and honesty characterize the just use of power. In contrast, the unjust application of power attempts to control another's actions against its will or without its understanding or in the absence of fault (Dwyer and Tanner 2002).

Distributive justice refers to the perceived fairness and equity of an organisation's rewards as compared to its inputs in a given process (Adams 1963). To maintain a repeated business exchange based upon norms of reciprocity, the respective physical inputs of each partner must be perceived as fair by the other partner (Homans 1958). Procedural justice refers to the fairness of the actual decision-making process, as opposed to the fairness of outcomes (Lind and Tyler 1988). For example, procedural justice may exist as consideration of one's opinions, the ability to partially influence or voice opinions in the decision-making process, consistency of the process, or timely feedback (Kim and Mauborgne 1993; Sapienza and Korsgaard 1996). 


\section{Basis of Theories}

Gender differences - specifically relevant to relationship communication and relationship dissolution - have been reliably documented. Five important insights from gender differences theories on building relationship can be summed up as follow (Fletcher 2002).

First, women tend to approach and communicate about relationship problems while men are more likely to avoid or withdraw from such interactions. Second, women are likely to talk to their friends more openly about their intimate relationships than are men. Third, women are better at mind-reading in relationships than are men. Fourth, women prefer men who adopt a good communication style, whereas the opposite is true for male preferences. Fifth, women develop more sophisticated explanations for their relationships breaking up than do men (Fletcher et al. 1992).

This list of gender differences adds up to a picture of women being more expert and motivated relationship psychologists than men, as more active in their relationship monitoring, and as more oriented toward the maintenance and success of their relationships.

Research indicates that communication problems are the major source of interpersonal difficulties. The notion that good communication helps produce successful and happy relationships is both widely expounded and accepted. Thus, it is important to explore the way women handle communication problems.

Relationship scientists typically define successful relationships in two ways - the extent to which relationships survive (stability) and the perceptions of relationship quality by partners in ongoing relationships. One could quibble with both methods of measuring relationship success. A couple may be relatively happy with the relationship, whereas the relationship may appear to an outsider as long past its use-by date.

Nevertheless, these two criteria of relationship success make intuitive sense. Both factors can be measured, and are important variables to assess in their own right, even if relationship success is construed in some broader fashion.

Almost everyone experiences dark or uncharitable emotions and thoughts in intimate relationships. Two competing theories have been advanced by relationship scientists specifying how individuals should best deal with such mental events: the good communication model and the good management model (Fletcher 2002).

The good communication model is based around three empirical postulates, describing what couples in successful relationships are supposed to do with their negative thoughts and emotions. First, they frankly express their negative feelings and cognitions (albeit in a diplomatic fashion). Second, they deal openly with conflict - they do not stonewall, withdraw, or go shopping. Third, they honestly attempt to solve their problems. If the problems are not dealt with, then it is believed they will stick around and eat away at the foundations of the relationship over time, or return at a later date possibly in a more corrosive and lethal form.

The good management model is also based around three empirical postulates. First, the regular and open expression of negative thoughts and feelings is posited as corrosive for relationships. Second, it is proposed that exercising good communication skills often involves compromise and accommodation to the partner's behavior (and not shooting from the hip with uncharitable emotions and cognitions). Third, relationships always have problems or issues that cannot be solved. People in successful relationships supposedly recognize them, accept them as insoluble, and put them on the cognitive backburner. They do not get obsessive about them, or fruitlessly struggle to solve them. 
Research showed that both men and women in happier marriages expressed their negative emotions and thoughts more frequently in problem-solving discussions (Gottman et al. 1998). Thus, the good communication model was supported.

In support of the good management model of relationship success, an extensive program of research by Rusbult, Arriaga, and Agnew (2000) and her colleagues has reported that people who have more successful relationships tend to sacrifice their own personal interests and needs, swallow hard, and ignore or respond positively to their partner's irritating or negative behaviors. In addition, studies of problem-solving behavior by Bradbury, Campbell, and Fincham (1995), among others, have shown that partners in happier relationships are more likely to ignore their partner's negative behavior or to respond to it in a benign fashion.

\section{Research Proposition}

Relationship marketing suggests that the dominant marketing function should be interaction. It has long been a tenet of exchange that firms engage in exchange for benefits and value, not products (Dunne 2001). Exchange will occur and be sustained if it is rewarding and if it provides greater value than the alternatives. Commercial relationships cannot be sustained unless each actor participating in the exchange anticipates that by so doing, its wants will be satisfied (Blois 2002). Furthermore, the exchange must be perceived as being fair by each of the transacting parties (Forker and Stannack 2000).

Reliable relationships among partners are important to ensure that the supply chain is efficient and effective and trigger innovation. Innovation and change require different actors to work together. Furthermore, as a multi-actors process is not a just a one-of event, but rather a series of activities carried out over time, involving much informal networking and communication behind the scenes, signify the importance of reliable long term relationships.

As business-to-business encompass multiple organisations and participants, the potential for conflict grows because its sources are embedded in the interaction system: functional differentiation between parties, actors heterogeneity, rewards and value sharing, forms and use of power. Conflicts may be caused by competition for resources, claim for credit and dissatisfaction over the partner performance, as well as by differences in perceptions and interpretations. An elementary potential for conflict is built into all social relationships. But serious conflict can exist between partners in supply chain. Whether viewed as threatening or productive, constraining or liberating, such conflict must be taken into account in analysing the performance of a supply chain.

The inter-organisational complexity of business-to-business relationship requires not only trust, but also offers the potential for conflict. Conflict is inherent in the very heterogeneity of collaborations, may be both disruptive and stimulating to the social fabric (Coser 1956; Assael 1969; DiStefano 1984; Alter 1990). Conflict need not be devastating, nor prevent the achievement of collaboration's goal. Inter-organisational conflicts may have destructive consequences. However, a reasonable level of conflict can be functional for each and every system (Coser 1956). One thing business marketer can learn from gender theories is that communication is central to the experience and management of conflict. What people say and how they say it signals their approach to resolving conflicts of interests. It is through communication that people express their desires, recognize differences, and attempt to resolve those differences. Putnam and Poole (1987) wrote that communication constitutes the essence of conflict in that it undergirds the formation of opposing issues, frames perceptions of the felt conflict, translates emotions and perceptions into conflict behaviors, and sets the stage for future conflicts. Crosby, Evans, and Cowles (1990) contend the style and intensity of the communication between individuals is critical in establishing and maintaining interpersonal relationships. 
Based on the above discussion, this paper posit the following proposition as characterizing three most common relationship styles that are both stable and bring about satisfaction in business-to-business relationship.

Proposition 1 is the good communication relationship. Business partners in this style adhere to the good communication model. They approach conflict, discuss problems in an open and honest fashion, and they sometimes communicate about the relationship itself - where it is going and whether it is helping firm to grow. The individual partners in these relationships tend to have liberal views. They consciously think about their relationships a lot, and enjoy talking about their relationships with their partners. They also nurture their relationships, and express admiration for one another frequently, but they value their individuality and freedom to grow.

Proposition 2 is the good management relationship. These firms avoid conflict, and seldom talk about their relationship or where it is going. They do not talk to each other about how hard they have to work on the relationship. They openly accept their closeness and dependency on one another, without becoming obsessive about their loss of individuality. They tend to be affectionate and warm with one another, but retain a rather rigid and traditional structure. These business partners are happy with ultra predictable and stereotyped interactions.

Proposition 3 is the volatile relationship. These organizations do not appear to fit either the good communication or the good management prototypes. They bicker and argue a lot over apparently minor things. They are feisty and assertive. They say what they think, when they think it. These relationships are not boring.

\section{Implication and Conclusion}

Relationship marketing emphasis that marketing should not ignored or underplayed the feelings of social man and encouraging marketers to behave as rational managers and as economic man (Eastburn in Lazer and Kelley, 1973). This paper addresses the question of why managed communication is so central to business enterprise.

Conceptually, good communication relationship can be measured using self-ratings questionnaires. It is possible to use the standard inside criterion; namely, how the relationship participants themselves perceive the quality of their communication. On the other, good management relationship can be obtained from partner perception. However, operational scales for these two constructs need to be carefully designed.

The contribution of this paper is twofold. First, it attempts to create more insight into areas where relationship marketing research to date has not been abundant. Although these suggestions for further research stem from an overview of studies in relationships studies and gender differences theories, ultimately all business relationships are relationship between people, not relationships between firms (Duffy, Fearne, and Hornibrook 2003). More research is still needed to explore relationship styles that are both stable and bring about satisfaction. Recent research has not filled in the identified knowledge gaps and has not succeeded in providing conclusive evidence within these areas.

Second, this paper attempts to contribute to methodological development of measuring relationship success by systematically distinguishing between good communication relationship and good management relationship. The purpose of this approach is to disentangle pure communication style effects from management style factors that may be correlated with relationship success. The separation of both effects may clear evidence of what constitutes relationship success. 


\section{References}

Adams, J. S. 1963. Toward an understanding of inequity. Journal of Abnormal and Social Psychology 67: 422-436.

Aldrich, H., and D. A. Whetton. 1981. Organization Sets, Action-Sets And Networks: Making The Most of Simplicity. In Handbook of Organizational Design, ed. P. C. Nystrom and W. H. StarbuckOxford: Oxford University Press.

Alter, C. 1990. An Exploratory Study of Conflict and Coordination In Interorganizational Service Delivery Systems. Academy of Management Journal 33 (3): 478-502.

Amason, A. 1996. Distinguishing Effects of Functional and Dysfunctional Conflict on Strategic Decision Making: Resolving a paradox for top management teams. Academy of Management Journal 39: 123-148.

Amason, A., and H. Sapienza. 1997. The Effects of Top Management Team Size and Interaction Norms on Cognitive and Affective Conflict. Journal of Management 23: 496-516.

Assael, H. 1969. Constructive Role of Interorganizational Conflict. Administrative Science Quarterly 14 (4): 573-582.

Bagozzi, R. P. 1975. Marketing as Exchange. Journal of Marketing 39 (3): 32-39.

Boulding, K. 1963. Conflict and Defense. New York: Harper \& Row.

Bowman, C., and V. Ambrosini. 2000. Value Creation Versus Value Capture: Towards a Coherent Definition of Value In Strategy. British Journal of Management 11: 1-16.

Bradbury, T. N., S. M. Campbell, and F. D. Fincham. 1995. Longitudinal and Behavioral Analysis of Masculinity and Femininity in Marriage. Journal of Personality and Social Psychology 68: 328-341.

Coser, L. A. 1956. The Functions of Social Conflict. Glencoe, III: The Free Press.

Crosby, L. A., K. R. Evans, and D. Cowles. 1990. Relationship Quality in Services Selling: An Interpersonal Influence Perspective. Journal of Marketing 54 (July): 68-81.

DiStefano, T. 1984. Interorganizational conflict: A Review of an Emerging Field. Human Relations 37 (5): 351-366.

Duffy, R., A. Fearne, and S. Hornibrook. 2003. Measuring Distributive and Procedural Justice. An Exploratory Investigation of The Fairness of Retailer-Supplier Relationships in The UK Food Industry. British Food Journal 105 (10): 682-694.

Dunne, A. J. 2001. Supply Chain Management: Fad, Panacea or Opportunity? Australasian Agribusiness Perspectives Paper 48: 1-30. www.agrifood.info/perspectives/2001/

Dwyer, F. R., and J. F. Tanner. 2002. Business marketing: Connecting strategy, relationship and learning 2nd ed. New York, NY: McGraw-Hill.

Fletcher, G. J. O. 2002. The new science of intimate relationships. Oxford: Blackwell Publishers.

Fletcher, G. J. O., R. J., G. Rhodes, and C. Lange. 1992. Accuracy and Speed of Causal Processing: Experts Versus Novices in Social Judgment. Journal of Experimental Social Psychology 28: 320-338.

Forker, L. B., and P. Stannack. 2000. Cooperation versus Competition: Do Buyers and Suppliers Really See Eye to Eye? European Journal of Purchasing and Supply Management 6: 31-40.

Foss, K., and N. Foss. 2002. Creating, capturing and protecting value: A property rights-based view of competitive strategy. DRUID Working Paper 02 (02):

Goldman, R. M. 1966. A Theory of Conflict Process and Organisational Offices. Journal of Conflict Resolution 10 (September): 335-340.

Gottman, J. M., J. Coan, S. Carrère, and C. Swanson. 1998. Predicting Marital Happiness and Stability from Newlywed Interactions. Journal of Marriage and the Family 60: 5-22.

Gronroos, C. 1990. Service Management and Marketing: Managing Moments of Truth in Service Competition. Lexington, Massachusetts: Lexington Books.

Gronroos, C. 1994. From Marketing Mix to Relationship Marketing. Toward a Paradigm Shift in Marketing. Management Decision 32 (2): 4-32. 
Holbrook, M. 1994. The nature of customer value: An Anthology of Services in The Consumption Experience. In Service quality: New directions in Theory and Practice, ed. R. T. Rust and R. L. Oliver, 21-71. Thousand Oaks, CA: Sage Publications.

Homans, G. C. 1958. Social Behaviour as Exchange. American Journal of Sociology 63: 597606.

Hunt, S. D. 1991. Modern Marketing Theory: Critical Issues in the Philosophy of Marketing Science. Cincinnati, $\mathrm{OH}$ : SouthWestern Publishing.

Ireland, R. D., and J. W. Webb. 2007. A Multi-Theoretic Perspective on Trust and Power in Strategic Supply Chains. Journal of Operations Management 25 (2): 482-497.

Jehn, K. 1997. A Qualitative Analysis of Conflict Types and Dimensions in Organizational Groups. Administrative Science Quarterly 42: 530-557.

Jehn, K., G. Northcraft, and M. Neale. 1999. Why Differences Make a Difference: A Field Study of Diversity, Conflict, and Performance in Workgroups. Administrative Science Quarterly 44: 741-763.

Kim, W. C., and R. A. Mauborgne. 1993. Procedural Justice, Attitudes, and Subsidiary Top Management Compliance. Academy of Management Journal 36: 502-526.

Lind, E. A., and T. Tyler. 1988. The Social Psychology of Procedural Justice. New York: Plenum.

Moller, K., and D. Wilson. 1995. Business Relationships: an Interaction Perspective. In Business marketing: An Interaction and Network Perspective, ed. K. Moller and D. WilsonNorwell, Massachusetts: Klewer.

Pinkley, R. 1990. Dimensions of the Conflict Frame: Disputant Interpretations of Conflict. Journal of Applied Psychology 75: 117-128.

Pondy, L. 1967. Organizational Conflict: Concepts And Models. Administrative Science Quarterly 12: 296-320.

Putnam, L. L., and M. S. Poole. 1987. Confict and Negotiation. Handbook of Organizational Communication ed. F. M. Jablin, L. L. Putnam, K. H. Roberts and L. W. Porter, 549-599. Newbury Park, CA: Sage.

Rentschler, R., ed. 1999. Innovative Arts Marketing. Sydney: Allen and Unwin.

Rusbult, C. E., X. B. Arriaga, and C. R. Agnew. 2000. Interdependence in Close Relationships. Blackwell Hand Book of Social Psychology: Interpersonal Processes, ed. G. J. O. Fletcher and M. S. Clark, 359-387. London: Blackwell.

Sapienza, H. J., and M. A. Korsgaard. 1996. Procedural Justice in Entrepreneur-Investor Relations. Academy of Management Journal. 39: 544-574.

Schmidt, S. M., and T. A. Kochan. 1972. Conflict: Toward Conceptual Clarity. Administrative Science Quarterly 17 (September): 359-370.

Stern, L. W. 1971. Antitrust Implications of a Sociological Interpretation of Competition, Conflict, and Cooperation In The Marketplace. The Antitrust Bulletin 16 (Fall): 509-530.

Storbacka, K., T. Strandvik, and C. Grönroos. 1994. Managing Customer Relationships for Profit: The Dynamics of Relationship Quality. International Journal of Service Industry Management 5 (5): 21-38.

Sydow, J. 1998. Understanding the Constitution of Interorganizational Trust. Trust within and between organizations, ed. R. Bachmann and C. Lane, 31-64. New York: Oxford University Press.

Thomas, S., and D. T. Wilson. 2003. Creating and Dividing Value In a Value Creating Network. 19th IMP-conference in Lugano, Switzerland.

\footnotetext{
*Tedy Herlambang is a academic staff of Ma Chung University. Any inputs, suggestions, or comments could be delivered through Email: tedy.herlambang@machung.ac.id or bangtedy@yahoo.com.au
} 